J. Product. \& Dev., 24(3): $517-535(2019)$

\title{
EFFECT OF OCTACOSANOL SUPPLEMENTATION ON PRODUCTIVE AND PHYSIOLOGICAL PERFORMANCE OF AGED SILVER MONTAZAH STRAIN DURING SUMMER SEASON.
}

\author{
I. El-Wardany ; A.A. Habeib ${ }^{2}$; Hanan S. Mohamed ${ }^{2}$ K; I. A. Fathey ${ }^{3}$ and \\ T. Rabie ${ }^{4}$ \\ ${ }^{1}$ Dept of Poult Production, Ain Shams University, Egypt. \\ ${ }^{2}$ Dept. of Poult. Breed. Res. ${ }^{3}$ Dept. of Poult. Nutr. Res., Egypt. \\ Anim. Prod. Res. Instit., Minis. of Agric., Giza, Egypt. \\ ${ }^{4}$ Dept. of Poult. Breed. Suez Canal University, Egypt.
}

\section{ABSTRACT:}

The objective of this study was to evaluate the impact of supplementation levels $(0,8,16$ and $24 \mathrm{mg}$ octacosanol (octa) / $\mathrm{kg}$ diet) on productive and physiological performance of aged Silver Montazah strain. A total number of 120 laying hens and 24 cocks of Silver Montazah local strain at 60 weeks of age was utilized in a completely randomized design and randomly assigned into 4 treatment groups (30 hens +6 cocks in each treatment). Each group was divided into three replicates (10 hens and 2 cocks in each replicates). The $1^{\text {st }}$ group was fed the basal diet and served as the control group. The $2^{\text {nd }}, 3^{\text {rd }}$ and $4^{\text {th }}$ groups were fed the basal diet supplemented with 8,16 , and $24 \mathrm{mg}$ octacosanol $/ \mathrm{kg}$ diet respectively.

The obtained results revealed that egg production percentage, egg mass, feed conversion ratios, concentrations of cholesterol, triglycerides, and LDL cholesterol, ovary weights, number of small yellow follicles (SYFs) and large white follicles (LWFs) were significantly $(P \leq 0.05)$ improved by supplemented at levels of $16 \mathrm{mg}$ or $24 \mathrm{mg}$ octa $/ \mathrm{kg}$ diet as compared with the control group. In addition, albumen height and Haugh unit were significantly $(P \leq 0.05)$ improved than the control group at level of $24 \mathrm{mg}$ octa $/ \mathrm{kg}$ diet. Yolk diameter, concentrations of total protein, progesterone, estradiol, FSH, and LH, sperm cell concentration as well as sperm motility, dead spermatozoa, sperm abnormality and acrosomal 
damage were significantly improved by increasing levels of octa when compared with the control group.

Conclusively, it is clear that, supplementation of $16 \mathrm{mg}$ octacosanol $/ \mathrm{kg}$ diet is recommended for improving most of productive and reproductive traits, including egg production, some parameters egg quality, of semen quality and reduce serum lipid of laying hens, during summer season, under Inshas, Sharkia Province, Egypt environment conditions.

Key words: Octacosanol, Laying Performance, Egg Quality, Serum Biochemical \& Hormone, Semen Quality.

\section{INTRODUCTION}

The reproductive performance of chicken females is known to deteriorate in accordance with age .The ovaries and particularly the follicles are the primary targets of senescence (Lebedeva et al., 2010). Various factors are associated with the initiation of the gradual decline in egg production in a flock of aging birds, which include the different sizes of yolk follicles as well as the changes in the pattern of yolk accumulation into the follicle and the high rate of atresia in the small follicles in addition to the slight transfers of follicles into rapid growth phase among old hens (Oguike et al., 2006). More subtle changes in levels of gonadotropins and sex steroids or due to follicular sensitivity to these steroids (Burger et al., 2002), furthermore, many results from subtle changes in levels of sex steroids such as time or amplitude of the preovulatory surge of hormones (Jonassen et al., 1991). Octacosanol [HO-CH2-(CH2)26CH3], a long-chain aliphatic alcohol with prominent physiological activity and pharmacological effects, is the main component of a natural wax product, which exists in wheat germ oil, rice bran oil, fruits, and leaves (Taylor et al., 2003; Oliveira et al., 2012). It is related in structure to vitamin E, octacosanol products are sometimes a mixture of very long chain aliphatic components, namely fatty acids , aldehydes , primary and secondary alcohols, ketones and alkanes of chain lengths C20 - C36, as well as, C38 - C70 alkyl esters (Bianchi, 1995 and Jetter et al., 2006). Octacosanol has a variety of biological activities activities, including antifatigue properties (Kim et al., 2003), antioxidant activities (Ohta et al., 2008), cholesterol-lowering effects (Hernandez et al., 1992), cytoprotective function (Carbajal et al., 1996). Furthermore, it is safety (Castano et al., 1995). Octacosanol is considered great development 
an application value as new feed additive, there are few studies on octacosanol in the domestic animals .However, recent studies, showed the dietary supplementation of octacosanol improved reproductive hormones, modulation development of reproductive organs, egg quality, feed efficiency and egg laying hens (Peng et al., 2016 and Long et al., 2017), as well as enhancement of body weight and feed efficiency in broilers (Xu and Shen 1997) and in Japanese quails (Wafar, 2017). Furthermore, studied have shown that octacosanol may affect on the reproductive system, particular, causing the secretion of gonadal hormones such as testosterone and cortisol (Wu, 2007), promoting chick comb growth (Ezra, 1963), increasing fertility in cows and increase sex drive in male animals (Deter, 1997). Long et al. (2017) found that dietary octacosanol supplementation elevated the concentrations of FSH, LH, E2, and P4, which was consistent with the report that octacosanol may increase hormonal and gonadotropic activity in humans (Deters, 1997).

Levels objective of this study was to evaluate the efficiency of dietary octacosanol supplementation on laying performance, egg quality and to confirm the reproduction promoting function of octacosanol through changes in hormone levels, ovarian development and number follicles, during summer season, under Inshas, Sharkia Governrate, Egypt environment conditions.

\section{MATERIALS AND METHODS}

The experimental work was carried out at the Inshas Poultry Research Station, Animal Production Research Institute, Agricultural Research Center, Giza, Egypt, during the period from June to Augusts 2018.

A total number of 120 laying hens and 24 cocks of Silver Montazah local strain at 60 weeks of age was utilized in a completely randomized design and randomly assigned into 4 treatment groups (30 hens +6 cocks / group) Each treatment was divided into three replicates (10 hens and 2 cocks). Laying hens of each group were nearly equal of average body weight $(1532 \pm 12.9)$ and initial egg production of approximately $33.87 \pm 3.78$ $\%$. A corn-soybean meal basal experimental layer diet $(15.89 \% \mathrm{CP}$ and $2704 \mathrm{kcal} \mathrm{ME} / \mathrm{kg}$ diet) was formulated to cover all recommended nutrient requirements according to Feed Composition Tables for Animal and Poultry Feedstuffs used in Egypt (2001) as shown in Table (1). The birds within each group were fed the basal diet supplemented with $0,8,16$ and $24 \mathrm{mg}$ 
octacosanol/kg diet in the $1 \mathrm{st}, 2 \mathrm{nd}, 3 \mathrm{rd}$ and 4 th groups, respectively from 60 to 72 weeks of age.

Table (1): Composition and calculated analysis of basal diet.

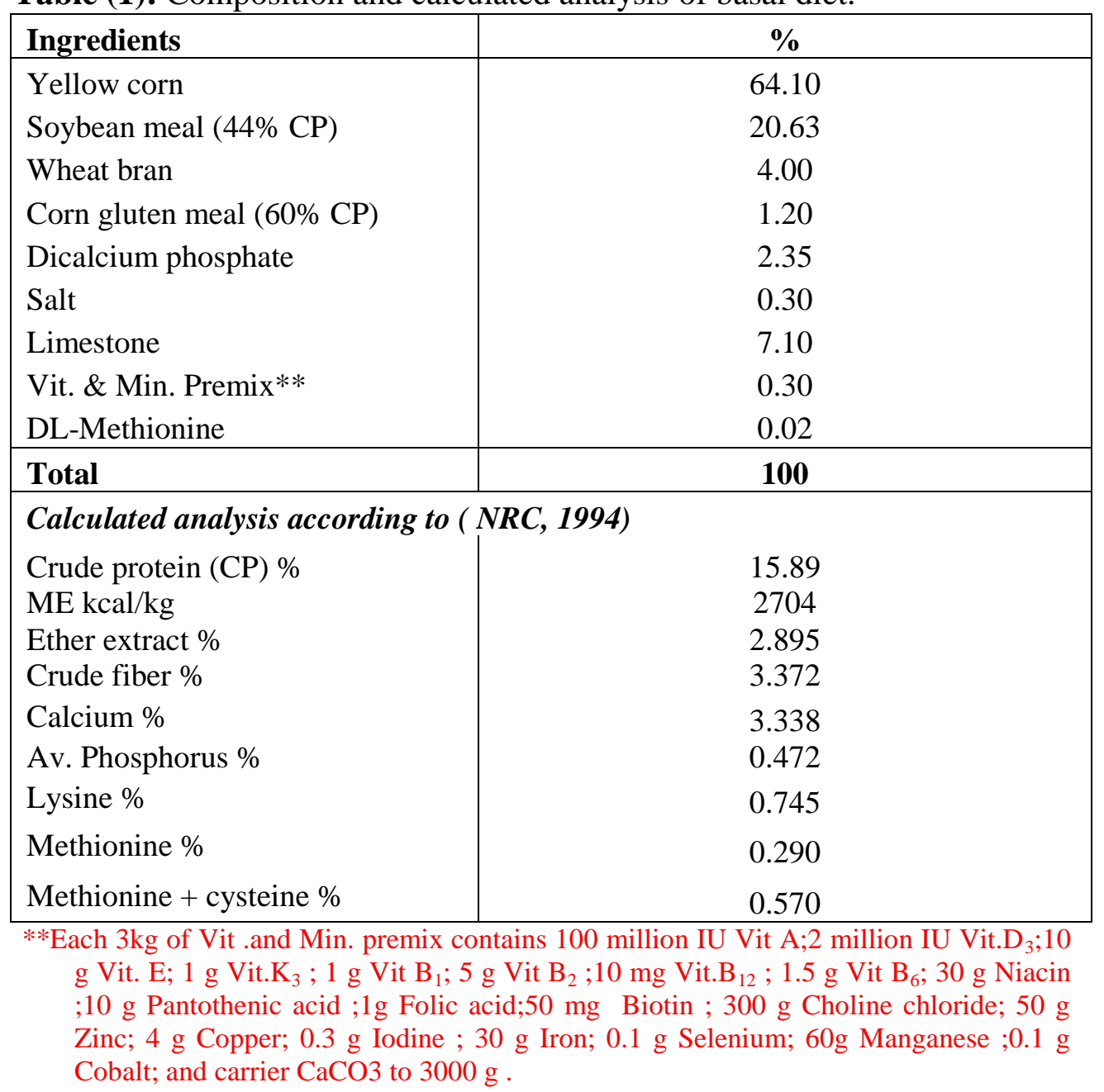

Minimum and maximum ambient temperatures averages during summer season ranged between 24.91 and $35.36{ }^{\circ} \mathrm{C}$, relative humidity from 22.27 to $79.63 \%$ and temperature-humidity index (THI) from 22.38 to $34.03 \%$ under Inshas, Sharkia Governrate, Egypt as shown in Table 2. 
Table (2): Means of air temperature, relative humidity and temperaturehumidity index (THI) during experimental period according to Egyptian Meteorological Authority, 2018 under environmental Sharkgia Governard condition.

\begin{tabular}{|l|c|c|c|c|c|c|}
\hline \multirow{2}{*}{$\begin{array}{c}\text { Summer } \\
\text { months }\end{array}$} & \multicolumn{2}{|c|}{$\begin{array}{c}\text { Averages temperature } \\
\left({ }^{\mathbf{0}} \mathbf{C}\right)\end{array}$} & \multicolumn{2}{c|}{$\begin{array}{c}\text { Averages } \\
\text { RH (\%) }\end{array}$} & \multicolumn{2}{c|}{$\begin{array}{c}\text { Averages } \\
\text { (THI) }\end{array}$} \\
\cline { 2 - 7 } & Min $^{*}$ & Max $^{* * *}$ & Min $^{*}$ & Max $^{* * *}$ & Min $^{*}$ & Max $^{* * *}$ \\
\hline June & $24.15 \pm 0.35$ & $35.28 \pm 0.5$ & $18 \pm 1.06$ & $75.67 \pm 2.16$ & 21.67 & 33.70 \\
\hline July & $25.18 \pm 0.21$ & $35.61 \pm 0.31$ & $23.3 \pm 0.99$ & $80.75 \pm 1.13$ & 22.62 & 34.34 \\
\hline August & $25.38 \pm 0.17$ & $35.18 \pm 0.18$ & $25.52 \pm 0.92$ & $82.46 \pm 0.99$ & 22.84 & 34.05 \\
\hline Averages & $24.91 \pm 0.24$ & $35.36 \pm 0.33$ & $22.27 \pm 0.99$ & $79.63 \pm 1.42$ & $\mathbf{2 2 . 3 8}$ & $\mathbf{3 4 . 0 3}$ \\
\hline
\end{tabular}

*=Minimum, **Maximum, RH=Relative humidity, THI=Temperature-humidity index

THI was estimated according to the formula by Marai et al. (2000) as follows:

$\mathrm{THI}=\mathrm{db}{ }^{\circ} \mathrm{C}-\left\{(0.31-0.31 \mathrm{RH})\left(\mathrm{db}{ }^{\circ} \mathrm{C}-14.4\right)\right\}$,

Where $\mathrm{db}{ }^{\circ} \mathrm{C}=$ Bulb temperature in Celsius and $\mathrm{RH}=\mathrm{RH} \% / 100$. The values obtained indicate the following: $<22.2=$ Absence of heat stress; 22.2 to $<23.3=$ Moderate heat stress: 23.3 to $<25.6=$ Severe heat stress and 25.6 and more $=$ Extreme severe heat stress.

All birds were housed individually in one cage under open housed system. Each cage was provided with feeder and automatic pipette drinkers. Birds were fed ad-libitum and fresh water was available at all the time during the experimental period. The photoperiod during the experimental period was fixed at $16 \mathrm{~h}$ light: $8 \mathrm{~h}$ dark program.Octacosanol used in this study was obtained from a crude octacosanol extract of rice bran wax (Huzhou Shengtao Biological Co., Ltd., Zhejiang, China). The diets were prepared freshly each 3 days at different of the experimental period.

\section{Productive performance:}

The body weight change of laying hens was calculated by the difference between finally and initial weight, while the egg number and egg weight were recorded daily and feed intake was calculated weekly. The egg production rate was calculated during the experimental period from 60 to 72 weeks of age. 
Where: Egg production rate $(\%)=$ Total of egg number /Total of hens $\mathrm{x}$ 100. Egg mass was calculated by multiplying egg number by average egg weight. Feed conversion (g feed/g egg) was also calculated, at 64, 68 and 72 weeks of age, about 45 eggs from each treatment group were collected and incubated.

\section{Physiological parameters:}

The rectal temperature (RT) of three birds were randomly selected out of each replicate was measured with a digital thermometer $(0.1 \mathrm{oC}$ accuracy) inserted into the rectum (colon) of the birds for one minute according to Yahav and McMurtry (2001).

Respiratory rate (RR) of the birds was taken as the number of breaths per minute. Data on RT and RR were collected two consecutive days in every week.

\section{Egg quality:}

At 64, 68 and 72 weeks of age, 9 eggs (three from each replicate) from each treatment were taken to study egg quality traits. Egg shape index \%, yolk index \%, albumen height, yolk diameter, eggshell thickness (mm), Haugh units and percentage of egg components (yolk. albumin and shell) were determined. Haugh unit score for each egg was calculated according to Haugh (1937).

\section{Blood samples:}

At the end of the experiment (72 wk of age), 6 hens from each treatment ( 2 hens/rep.) were randomly chosen and sacrificed by cervical dislocation, and their abdomens were dissected. Blood samples were collected into coagulation tubes.

Serum was isolated by centrifugation at $3,000 \mathrm{rpm}$ for $10 \mathrm{~min}$ at $4{ }^{\circ} \mathrm{C}$ and immediately stored at $-20{ }^{\circ} \mathrm{C}$ until required for the analysis of biochemical parameters, including total protein (TP), albumin (ALB), total cholesterol, triglycerides, HDL cholesterol and LDL cholesterol were determined in blood serum using commercial kits (Bio-Diagonosis Co., Cairo, Egypt), following the same steps as described by the manufacturers. Also, estradiol (E2), progesterone (P4), follicle-stimulating hormone (FSH), and luteinizing hormone (LH) were estimated for females by Immunoenzymatic assay (ELISA), using standard kits.

Ovarian weight and numbers of the different-sized follicles: 
The ovaries were removed and weighed, and the numbers of preovulatory follicles (POFs) ( $>10 \mathrm{~mm}$ in diameter), small yellow follicles (SYFs) (4 to $10 \mathrm{~mm}$ in diameter), and large white follicles (LWFs) (2 to 4 $\mathrm{mm}$ in diameter) then the POFs, SYFs, and LWFs were carefully removed from the ovaries and counted, as described by Gilbert et al. (1977).

\section{Semen quality:}

Semen was evaluated immediately after collection from cocks and artificially inseminated to hens (cock/5 hens) two times per week. Semen tests were exclusively gathered toward the end of test period by the abdominal massage method from all cocks.

Immediately after semen collection, semen ejaculate volume was measured using graduate collecting tubes. Hydrogen-ion concentration $(\mathrm{pH})$ was measured by Universal Indicator Paper and Standard Commercial Stain. A drop of semen with the aid of a micro-pipette was placed on a pre warmed microscope slide, which was then covered with a glass cover slip and examined at a magnification of $\times 400$. Several fields were examined and an estimate to the nearest $10 \%$ of the motile sperm was made. Motility of semen samples was expressed as the percentage of motile spermatozoa having moderate to rapid progressive movement and cells that are motile under their own power (Ommati et al., 2013).

At least 10 microscopic fields were examined for each semen sample. Eosin-Nigrosine stain was used to determine the percent of morphologically sperm abnormalities and dead spermatozoa. For sperm cell concentration (X $10 \%$ ml) a droplet of diluted semen (1:200 in distilled water), semen was tenderly put on both councils of a Neubauer hemocytometer and the number of spermatozoa was determined microscopically (Ommati et al., 2013). Acrosomal damage of spermatozoa was determined according to Waston (1975).

\section{Statistical analysis:}

Data were analyzed by the least square analysis of variance according to Snedecor and Chochran (1982) using the General Linear Model Procedure (SAS, 2004) at the 5\% level of significance as the following model:

$$
\mathrm{Y}_{\mathrm{ijk}}=\mu+\mathrm{T}_{\mathrm{i}}+\mathrm{R}_{\mathrm{j}}+\mathrm{e}_{\mathrm{ijk}}
$$

Where: $Y_{i j}=$ Any observation, $\mu=$ Overall mean, $T_{i}=$ Effect of treatment group $(i=1 \ldots 4)$., $R=$ Replicates $(J=1,2,3), e_{i j}=$ Experimental random error.

All percentages, data were transferred to percentage angle using arcsine equation before subject to statistical analysis. 
Significant differences among means were tested using Duncan's New Multiple Range Test (Duncan, 1955).

\section{RESULTS AND DISCUSSION}

\section{Productive performance:}

As shown in Table (3) total body weight change, daily feed intake and viability percentage insignificantly affected by dietary supplementation of octacosanol in the diet of aged Silver Montazah strain at late laying phase (60 WK) as compared with the control. However, egg production percentage, egg mass and feed conversion ratios were significantly $(\mathrm{p}<0.05$ or 0.01 ) improved by supplement at levels of $16 \mathrm{mg}$ or $24 \mathrm{mg}$ octa $/ \mathrm{kg}$ diet as compared with group of control. While, egg weights had achievement an increase trend with the three levels of octacosanol but there was no significant difference between the control and treated groups. This may be due to that experimental treatment leading to regulates reproductive function, elevated sex steroids, reactivity of follicles and elevated the synergism effects between reproductive hormones, organs and their receptors which in turn enhancement egg production rate (Long et al., 2017). While unchanged egg weights could be attributed to increasing number of follicles which enter the final phase of rapid growth and thereby increasing competition between follicles for circulating vitellogenine (Sinervo, 1990). These results were similar with Peng et al.( 2016) who found that egg production, egg mass egg weight and feed conversion ratio were significantly improved by addition of octacosanol in the diet of laying hens $(38 \mathrm{WK})$ at levels of $9 \mathrm{mg}$ or $18 \mathrm{mg}$ or $27 \mathrm{mg}$ octa $/ \mathrm{kg}$ diet, while, Long et al. ( 2017) observed that these traits enhancement but egg weight unchanged by addition of octacosanol at levels of $5 \mathrm{mg}$ or $10 \mathrm{mg} / \mathrm{kg}$ diet in the diet of laying hens( $70 \mathrm{WK})$.

\section{Egg quality traits:}

Data presented in Table (4) indicated that egg shape index, yolk index , and relative weights of yolk ,albumen and shell and shell thickness insignificantly affected by dietary octacosanol levels supplementation. However, albumen height and Haugh unit were significantly $(\mathrm{P}<0.05)$ improved than the control group at level of $24 \mathrm{mg}$ octa. $/ \mathrm{kg}$ diet, while supplement of the two other levels of octa resulted in a numeric increase when compared with the control group. Furthermore, there was no 
significant differences among treated groups of these parameters. Nevertheless, yolk diameter was significantly $(\mathrm{P}<0.01)$ increased by increasing levels of octa when compared with the control group. This may
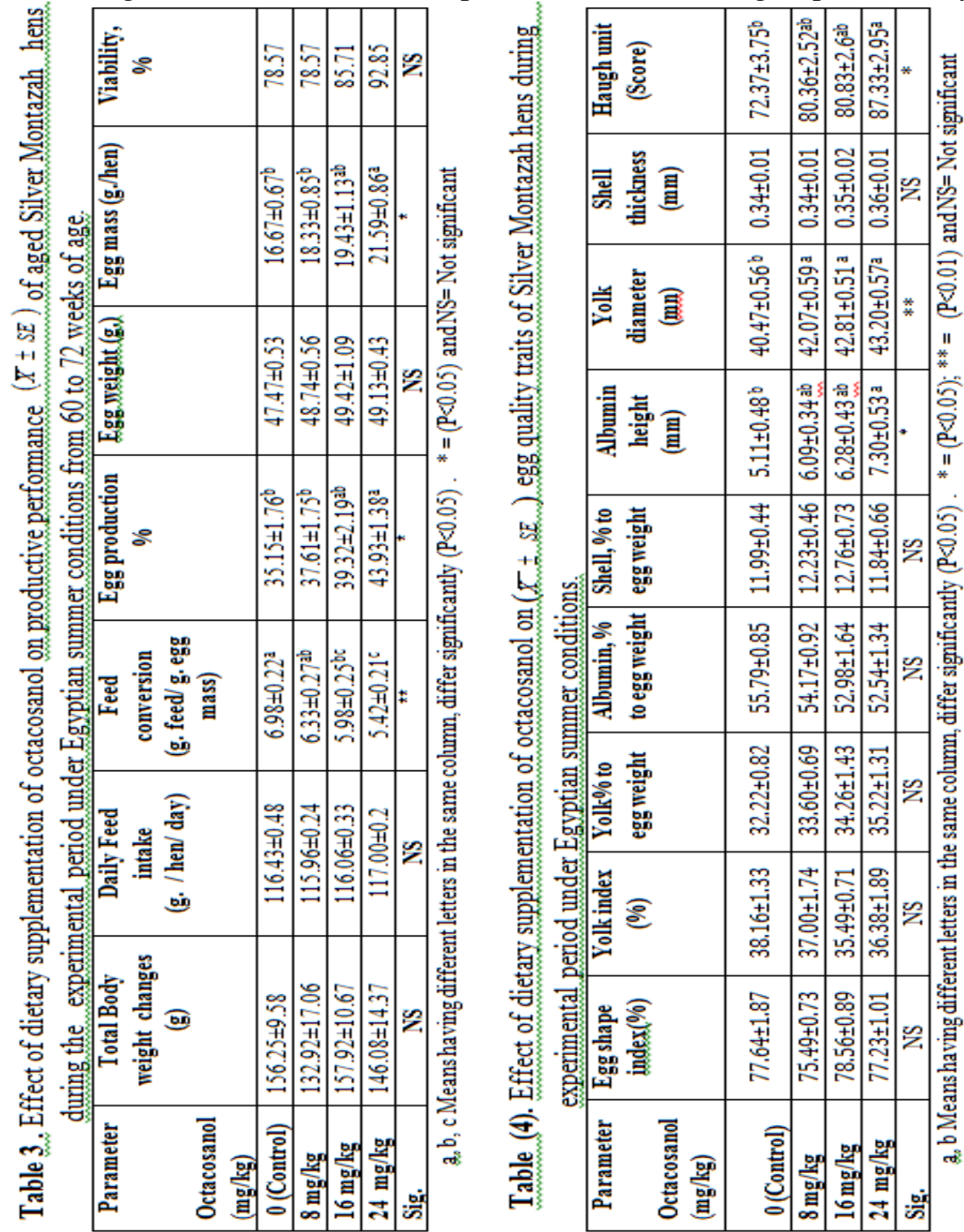
be due to that experimental supplement leading to change reproductive system from low functional state to high functional state, accordingly, the yolk formation and deposition in hens depends largely on the function of the liver- blood -ovary axis under complex regulation of diverse hormones especially estrogen (Yilmaz et al., 2015) ,this coincidence with Jamieson (2007) who found that increased levels of estrogen stimulate the production of yolk precursors by the liver and albumen by the oviduct. The present results were similar with peng et al. (2016) and Long et al. (2017) who observed that addition of octacosanol resulted in a significant increase in albumen height and Haugh unite. However, egg shell thickness and egg shape index insignificantly affected by treatments of octa. levels (Table 4).

\section{Blood traits:}

The results in Table (5) showed that concentrations of total protein in blood serum were significantly increased as compared with the control by used of the three levels of octacosanol. While, albumen and globulin values had been achievement a increase trend without a significant change when compared with the control group. These results were similar with Long et al. (2017) who found that total protein levels were significantly affected by dietary octacosanol supplementation $(0,5$, or $10 \mathrm{mg}$ octacosanol $/ \mathrm{kg} \mathrm{diet})$. While, disagreement results with James et al. (2017) who observed that total protein, albumen and globulin insignificantly affected by addition of octacosanol in the diet of Japanese quails at level of $0,5,15$, or $25 \mathrm{mg}$ octacosanol. With regard to, concentrations of cholesterol, triglycerides, and LDL cholesterol were lower significantly $(\mathrm{P}<0.05)$ at levels of $16 \mathrm{mg}$ or 24 $\mathrm{mg}$ octa/kg diet than the control group. While, these traits significantly unchanged as compared with the control and at level of $8 \mathrm{mg}$ octa/kg diet. However, HDL cholesterol was similar among experimental groups and control group. This may be partly attributable to that octacosanol regulate some enzymatic activities in lipid metabolism (Kato et al., 1995 and Mas et al., 2004 ). These results were agreement with Peng et al. (2016) who reported that a significant decrease of these traits by dietary supplementation of octacosanol in the diet of laying hens at levels of $18 \mathrm{mg}$ or $27 \mathrm{mg}$ octa $/ \mathrm{kg}$ diet. 
Data presented in Table (6) showed that concentrations of progesterone, estradiol, FSH , and LH were significantly $(\mathrm{P}<0.01)$ increased than the control group by experimental supplementation levels of octa. These results were agreement with that obtained by Long et al. (2017) who 


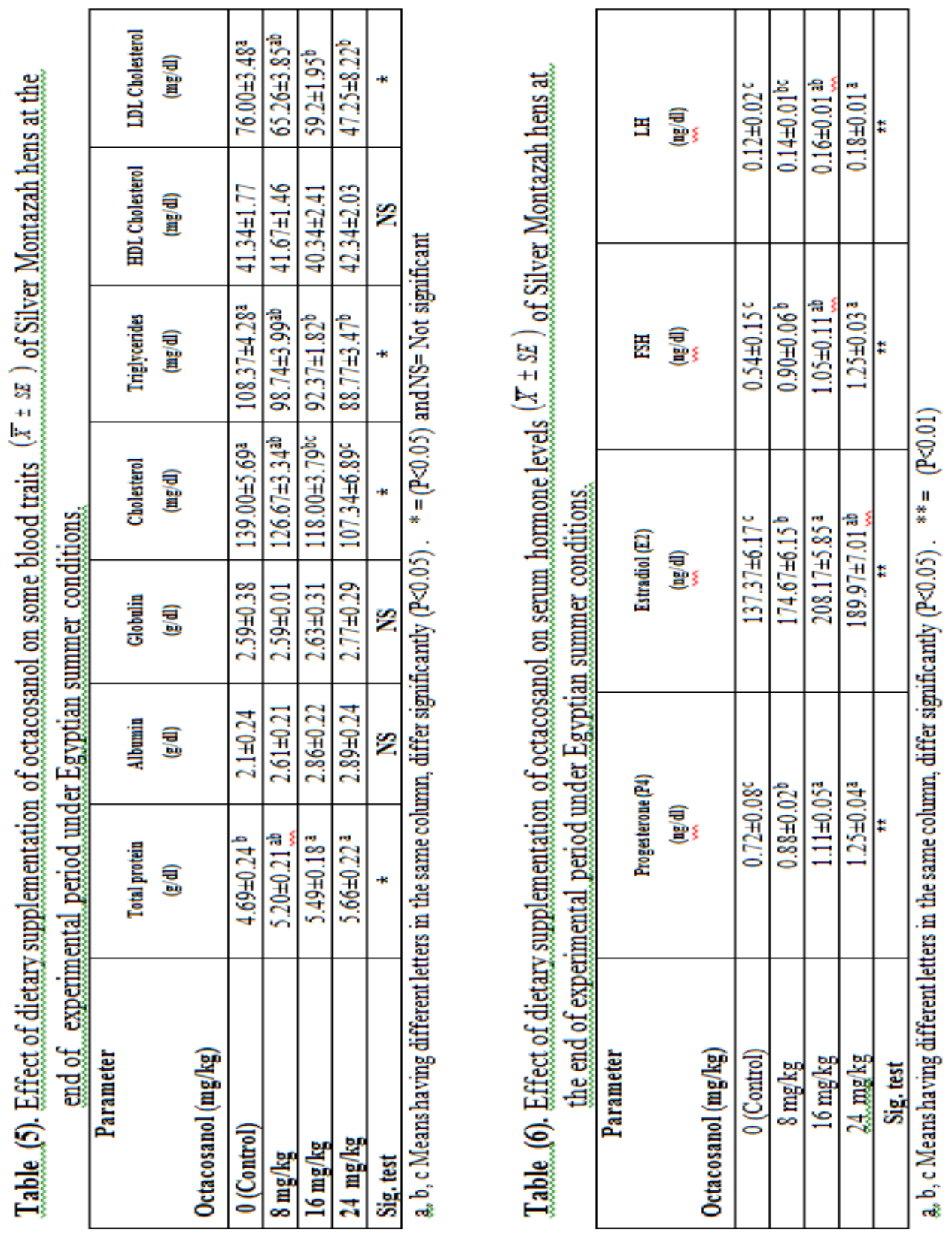


found a significantly enhancement in $\mathrm{P} 4, \mathrm{E} 2, \mathrm{FSH}$ and $\mathrm{LH}$ by addition of octacosanol in the diet of laying hens, as well as , Deter (1997) reported that octacosanol may increase hormonal and gonadotropic activity in human.

\section{Semen quality traits:}

Table (7) revealed that semen-ejaculate volume was significantly decreased by addition of octacosanol at level of $24 \mathrm{mg}$ octa $/ \mathrm{kg}$ diet. While, it did not significantly difference with the other two levels. However, sperm cell concentration achieved a significant increase trend with all levels of octacosanol as compared with the control group as well as sperm motility, dead spermatozoa, sperm abnormality and acrosomal damage were significantly ( $\mathrm{p}<0.05$ or 0.01 ) improved by using $8 \mathrm{mg}$ or $16 \mathrm{mg}$ or $24 \mathrm{mg}$ octa $/ \mathrm{kg}$ diet. Group fed diet $24 \mathrm{mg}$ octa $/ \mathrm{kg}$ achieved the best values of semen traits except for semen-ejaculate volume which was the lowest value. This may be due to that supplementation of octacosanol causing activity endocrine system, particularly increasing secretion of gonadal hormones such as testosterone and cortisol (Wu, 2007). Similarly, previous studies have shown that octcosanol promoting chick comb growth (Ezra, 1963), increasing sex drive in male animals (Deter, 1997)

\section{Ovary weights and number of different size follicles:}

Data in Table (8) indicated that ovary weights were significantly ( $p<0.05$ or 0.01 ) hevest of addition 16 and $24 \mathrm{mg}$ Oct./kg diet than groups of control and that fed $8 \mathrm{mg}$ octa/ $\mathrm{kg}$ diet, but number of preovulatory follicles (POFs) has been achievement a numeric increase trend with the three levels of octacosanol. Also, both number of small yellow follicles( SYFs) and large white follicles ( LWFs) were significantly ( $\mathrm{p}<0.05$ or 0.01 ) at 16 and $24 \mathrm{mg}$ Oct./kg diet higher than group of control that receiving $8 \mathrm{mg}$ octa $/ \mathrm{kg}$ diet. These results were similar with Long et al. (2017) who found that ovarian weight and number of follicles were significantly enhancement by addition of octacosanol in the diet of laying hens during late phase. These may be due to synergistic elevation between reproductive hormones and their receptors caused by octacosanol allows for the increase of ovarian weight and follicular numbers, as well as follicle growth, development, maturation, and ovulation in the ovary rapidly, which is favorable to improve the reproduction of laying hens in late laying period (Long et al., 2017). 


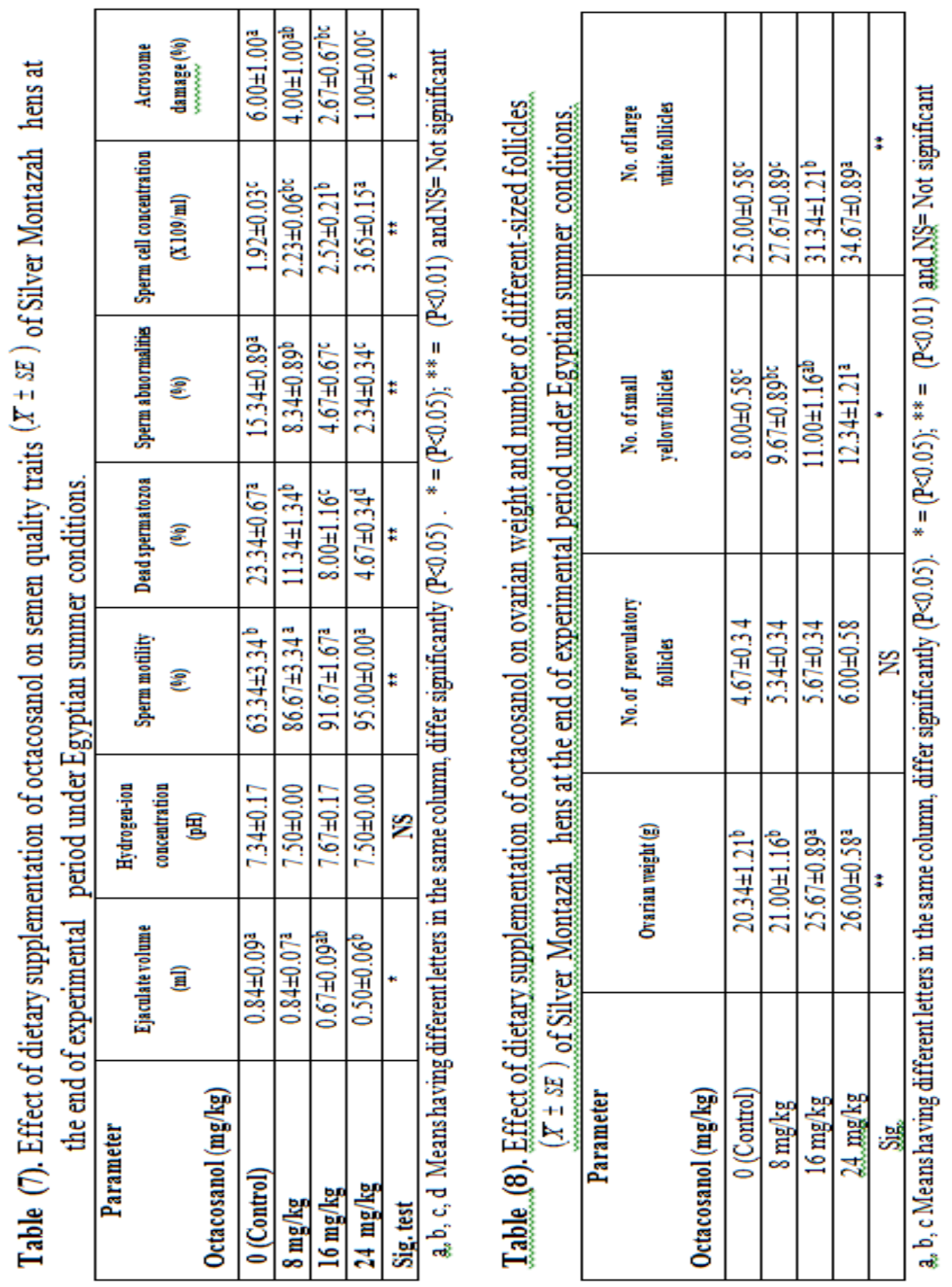


Conclusively, the results showed that supplementation of $16 \mathrm{mg}$ octacosanol $/ \mathrm{kg}$ in the diet of Silver Montazah chickens strain leading to a significant improvement in productive, reproductive and immunity performance, the best values has been achievement at level of $16 \mathrm{mg}$ octacosanol $/ \mathrm{kg}$ as compared with control group under summer season conditions in Egypt.

\section{REFERENCES}

Bianchi, G.; 1995. Plant waxes. In: Hamilton, RJ, editor. Waxes: Chemistry, Molecular Biology and Functions. Dundee, UK: Oily Press: 175-222.

Burger, L.L.; Dalkin, A.C.; Aylor, K.W.; Haisenleder, D.J. and Marshall, J.C., 2002. GnRH pulse frequency modulation of gonadotropin subunit gene transcription in normal gonadotropes-assessment by primary transcript assay provides evidence for roles of $\mathrm{GnRH}$ and follistatin. Endocrinology. 143:3243-3249.

Carbajal, D.; Molina, V.; Valdes, S.; Arruzazabala, L.; Rodeiro, I.; Mas, R. and Magraner. J., 1996. Possible cytoprotective mechanism in rats of D-002, an anti-ulcerogenic product isolated from beeswax. J. Pharm. Pharmacol. 48:858-860.

Castano, G.; Mas, R.; Nodars, M. Illnait, J.; Fernandez, J. C., 1995. One year study of the efficacy and safety of policosanol (5 mg twice daily) in treatment of type hypercholesterolemia. Curr. Ther Res. 56: 296-304.

Deters, T., 1997. Octacosanol-Energy in a Pill. Head Neck Pathol. 58:198199.

Duncan, D.B., 1955. Multiple range and multiple F tests. Biometrics, 11:1-42.

Ezra, L., 1963. Effects of octacosanol on chick comb growth. Proc. Soc. Exp. Biol. Med. 112:331-334.

Feed Composition Tables For Animal and Poultry Feedstuffs Used In Egypt, 2001. Technical Bulletin No.1, central lab for Feed and food; Ministry of Agriculture, Egypt.

Gilbert, B.; Evans, A. J.; Perry, M. M. and Davidson, M. H., 1977. A method for separating the granulosa cells, the basal lamina and the theca of the preovulatory ovarian follicle of the domestic fowl (Gallus domesticus). J. Reprod. Fertil. 50:179-181.

Haugh, R. R., 1937. The Haugh unit for measuring egg quality. United States. Egg Poult. Magazine, 43: 572- 573. 
Hernandez, F.; Illait, J.; Mas, R.; Castano, G.; Fernandez, L., Gonzalez, M.; Cordovi, N. and Fernandez, J. C. 1992. Effects of policosanol on serum lipids and lipoproteins in healthy volunteers. Curr. Ther. Res. 51:568-575.

James,W.R.; Ebere, O.P.; Isa, T.L.; Samuel, I.D. and Ibrahim, $\quad$ S.I., 2017. Growth performance, carcass characteristics and blood profile of Japanese quails fed dietary octacosanol. Mayfeb Journal of Agricultural Science. 1:23-28.

Jamieson, B.G.M., 2007. Reproductive biology and phylogeny of bird's volume 6a of series: phylogeny, morphology, hormones, fertilization. Science Publishers: School of Integrative Biology, University of Queensland. St. Lucia, Queensland, Australia.

Jetter, R; Kunst L. and Samuels, A.L., 2006. Composition of plant cuticular waxes. In: Riederer M, Muller C, editors. Biology of the Plant Cuticle. Oxford, UK: Blackwell Publishing: 182-215.

Jonassen, J. A.; Baker, S. P. and McNeilly, A. S., 1991. Long-term hyperprolactinaemia reduces basal but not androgen-stimulated oestradiol production in small antral follicles of the rat ovary. J. Endocrinol. 129:357-362.

Kato, S.; Karino, K. I.; Hasegawa, S.; Nagasawa, J.; Nagasaki, A.; Eguchi, M.; Ichinose, T.; Tago, K.; Okumori, H.; Hamatani, K.; Takahashi, M.; Ogasawara, J.; Masushige, S. and Masushige, S., 1995. Octacosanol affects lipid metabolism in rats fed on a highfat diet. British Journal of Nutrition , 73:433-441.

Kim, H.; Park, S.; Han, D. S. and Park, T., 2003. Octacosanol supplementation increases running endurance time and improves biochemical parameters after exhaustion in trained rats. J. Med. Food. 6:345-351.

Lebedeva, I.Y.; Lebedev, V.A.; Grossmann, R. and Parvizi, N., 2010. Agedependent role of steroids in the regulation of growth of the hen follicular wall. Reprod Biol Endocrinol., 8:15.

Long, L.; Wu, S.G.; Yuan, F.; Zhang, H. J.; Wang, J. and Qi, G.H. 2017. Effects of dietary octacosanol supplementation on laying performance, egg quality, serum hormone levels, and expression of genes related to the reproductive axis in laying hens. Poultry Science. 96 (4): 894-903. 
Marai, I.F.M.; Bahgat, L.B.; Shalaby, T.H. and Abdel-Hafez, M.A., 2000. Fattening performance, some behavioral traits and physiological reactions of male lambs fed concentrates mixture alone with or without natural clay, under hot summer of Egypt. Annals of Arid Zonne, $\underline{39}$ (4): 449-460.

Mas, R.; Castano, G.; Femandez, J.; Gamez, R.; Illnait, J.; Fernandez, L.; Lopez, E.; Measa, M.; Alvarez, E. and Mendoza, S., 2004. Long term effects of policosanol on obese patients with type II hypercholesterolemia. Asia Pac. J. Clin. Nutr. 13: 102.

Oguike, M. A.; Igboeli, G. and Ibe, S. N. 2006. Effect of Induced-moult on the Number Small Ovarian Follicles and Egg Production of Old Layers. Int. J. Poult. Sci.,5:385-389.

Ohta, Y.; Ohashi, K.; Matsura, T.; Tokunaga, K.; Kitagawa, A. and Yamada, K,. 2008. Octacosanol attenuates disrupted hepatic reactive oxygen species metabolism associated with acute liver injury progression in rats intoxicated with carbon tetrachloride. J. Clin. Biochem. Nutr. 42:118-125.

Oliveira, A. M.; Conserva, L. M.; De Souza Ferro, J. N.; Almeida Brito, F.; Lyra Lemos, R. P. and Barreto, E., 2012. Antinociceptive and anti-inflammatory effects of octacosanol from the leaves of sabicea grisea var. grisea in mice. Int. J. Mol Sci., 13:1598-1611.

Ommati, M. M.; Zamiri, M. J.; Akhlaghi, A.; Atashi, H.; Jafarzadeh, M. R.; Rezvani, M. R. and Saemi, F., 2013. Seminal characteristics, sperm fatty acids, and blood biochemical attributes in breeder roosters orally administered with sage (Salvia officinalis) extract. Anim. Prod. Sci., 53:548-554.

Peng, K.; Long, L.; Wang, X. and Wang, S., 2016: Effects of octacosanol extracted from rice bran on the laying performance egg quality and blood metabolites of laying hens. Asian Aust. J. Anim. Sci., 29 : (10) 14581463.

SAS Institute., 2004. SAS / DSTAT Users Guide. SAS Institute Inc., Cary, Nc.

Sinervo, B. 1990. The evolution of maternal investment in lizards: an experimental and comparative analysis of egg size and its effects on offspring performance. Evolution , 44: 279-294

Snedecor, G.W. and Cochran, W.G., 1982. Statistical Methods. $7^{\text {th }}$ Edition, Iowa State University Press, Towa, 511.

Taylor, J. C.; Rapport, L. and Lockwood, G. B., 2003. Octacosanol in human health. Nutrition, 19:192-195. 
Wafar, J. J., 2017. Growth performance, carcass characteristics and blood profile of Japanese quails fed dietary octacosanol. J. of Agric. Sci., $\underline{1}$ : 23-28.

Watson, P. F., 1975. Use of Giemsa stain to detect changes in acrosomes of freezing ram spermatozoa. Vet. Res., 97:12-15.

Wu, M. M., 2007. The effects of octacosanol supplementation on some biochemistry indexes in athletes. Master Thesis. Beijing Sport University. (in Chinese).

Xu, R. P. and Shen, H., 1997. Application of octacosoanol in broilers diet. Feed Res., 5: 26 (In Chinese).

Yahav, S. and McMurty, J. P., 2001. Thermotolerance acquisition in broiler chickens by temperature condition early in life. The effect of timing and ambient temperature. Poult. Sci., 80: 1662-1666.

Yilmaz, O.; Prat, F.; Ibañez, A.J., et al., 2015. Estrogen-induced yolk precursors in European sea bass, Dicentrarchus labrax: status and perspectives on multiplicity and functioning of vitellogenins. Gen Comp Endocrinol., 221:16-22.

$$
\begin{aligned}
& \text { تأثير إضافة الأوكتاكوزانول على الأداء الانتاجى والفسيولوجي لسلالة }
\end{aligned}
$$

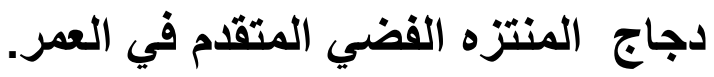

$$
\begin{aligned}
& \text { إبراهيم الورداني'، عرفات عبد الهادي حبيب، حنان صابر محمدّ، إبراهيم عبد الحميد فتحيّ، }
\end{aligned}
$$

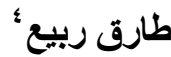

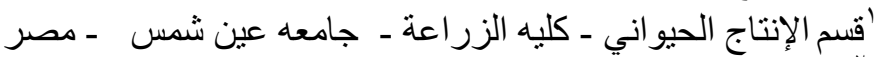

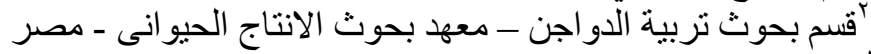

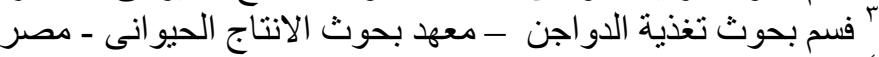

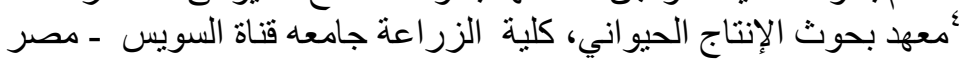

$$
\begin{aligned}
& \text { الهدف دن هذه الدراسة هو تقييم تأثنير أضسافه الاوكتاكوز انول علي تحسين الأداء }
\end{aligned}
$$

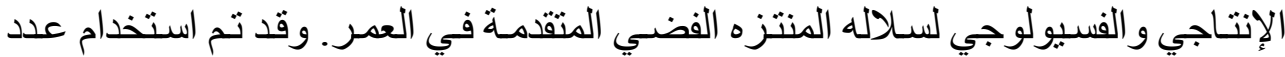

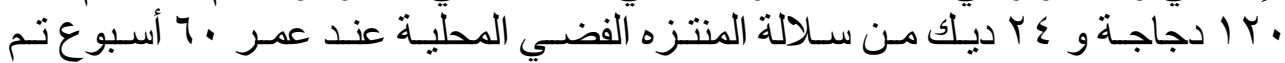

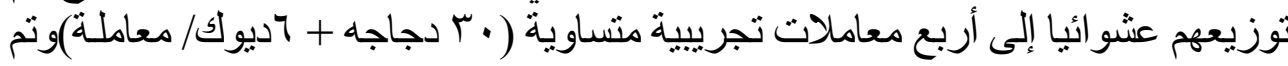

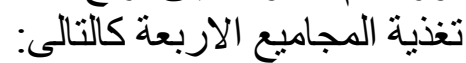

$$
\begin{aligned}
& 1 \text { ـ المعاملة الاولى :(كنترول) تتخذى فيها الطيور على الطعلى العليقة الأساسية بدون أى اضافة . }
\end{aligned}
$$


r ا المعاملة الثانيـة: تتخذى فيها الطيور على العليقة الأساسية مضـاف اليها م ملليجرام

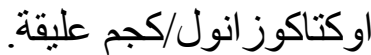

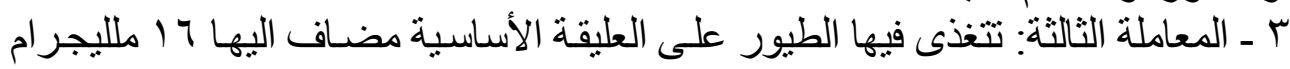
اوكتاكوز انول/كجم عليقة. عـ المعاملة الر ابعة: تتذذى فيها الطيور على العليقة الأساسية مضاف اليها ؟ ؟ ملليجرام اوكتاكوز انول/كجم عليقة.

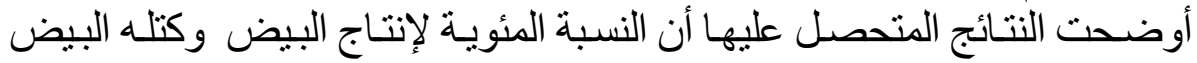

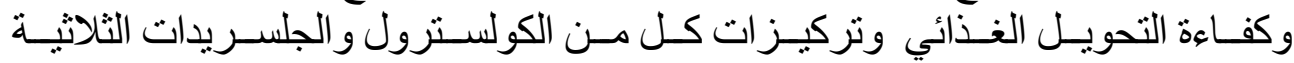

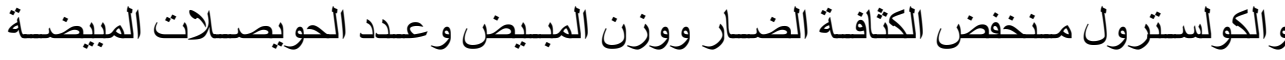

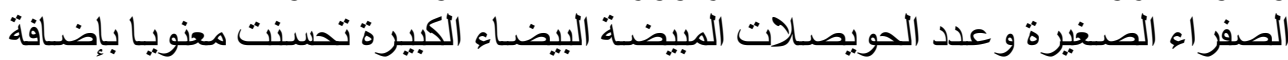

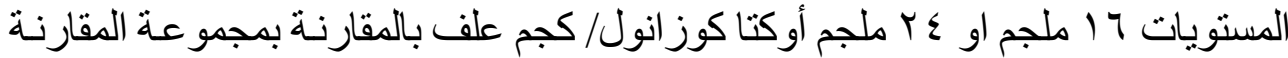

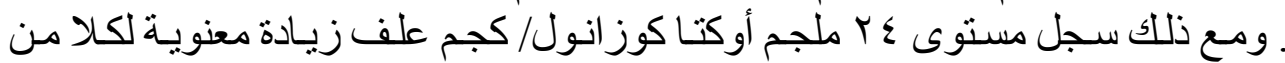

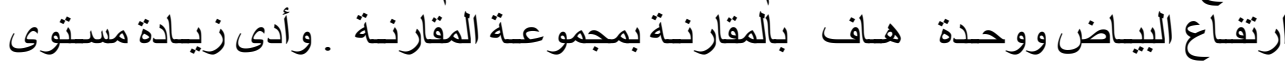

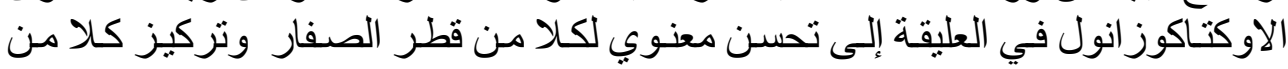

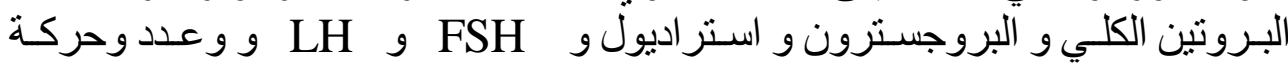

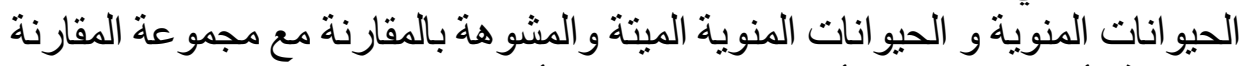

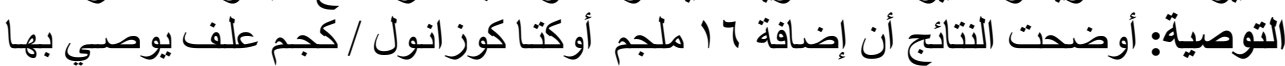

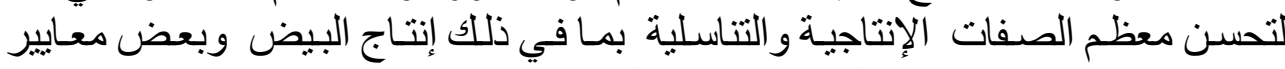

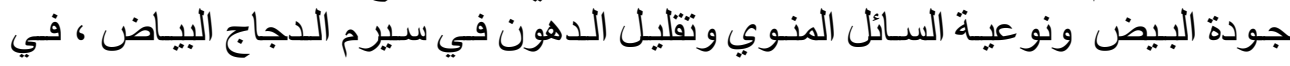

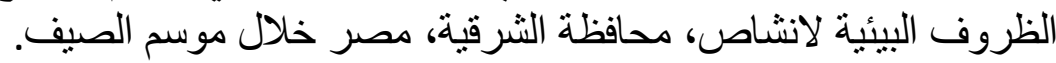


